\title{
Computer Simulation on Global Atmospheric Transport of Mercury by GEOS-Chem/GCAP
}

\author{
Xiaobo Zhu \\ National Computer Network Emergency Response Technical Team/Coordination Center of China
}

\begin{abstract}
Simulation is the imitation of the operation of a real-world process or system which is a common method for scientific analysis. A model is required here to represent the key characteristics, behaviors and functions of the selected physical or abstract system or process. The global 3-D atmospheric model (GEOS-Chem) we use in this paper can show the mercury concentrations for elemental mercury $(\mathrm{Hg}(0))$, divalent mercury $(\mathrm{Hg}(\mathrm{II}))$ and primary particulate mercury $(\mathrm{Hg}(\mathrm{P}))$. We do the simulation of mercury in the atmosphere for two 3-year periods (1999-2001 and 2049-2051), with the first 3 years (1999-2001) used for getting the 3-year average value of $\mathrm{Hg}(0), \mathrm{Hg}(\mathrm{II})$ and $\mathrm{Hg}(\mathrm{P})$, respectively in 2000 and the last 3 years (2049-2051) used for getting the 3-year average value of $\mathrm{Hg}(0), \mathrm{Hg}(\mathrm{II})$ and $\mathrm{Hg}(\mathrm{P})$, respectively in 2050. From the model results, we can see that the climate change from 2000 to 2050 would decrease $\mathbf{H g}(0)$ surface concentration in most of the world, only except in couple very small parts, for example north-eastern of China, south-eastern of South Africa and central part of Europe. The climate change from 2000 to 2050 would increase $\mathbf{H g}$ (II) surface concentration in most of mid-latitude continental parts of the world, such as the whole Africa continent and the major part of south Asia. At the same time, decrease $\mathrm{Hg}$ (II) surface concentration in most of highlatitude part of the world.
\end{abstract} 2050

Keywords—simulation platform; GEOS-Chem; Global; 2000-

\section{INTRODUCTION}

Simulation is the imitation of the operation of a real-world process or system. A model is required here to represent the key characteristics, behaviors and functions of the selected physical or abstract system or process. The model also represents the system itself, whereas the simulation represents the operation of the system over time. In this paper, we use GEOS-Chem/GCAP Model which is described in the following part of the paper. Simulation is used in many contexts, such as simulation of technology for performance optimization, safety engineering, testing, training and education. Simulation is also used with scientific modelling of natural systems or human systems to gain insight into their functioning, as in economics. Simulation can be used to show the eventual real effects of alternative conditions and courses of action. Simulation is also used when the real system cannot be engaged, because it may not be accessible, or it may be dangerous or unacceptable to engage, or it is being designed but not yet built, or it may simply not exist (https://en.wikipedia.org/wiki/Simulation). We focus on the model simulation of the mercury data for year 2000 and 2050. From the simulation, we try to get conclusion about how climate changes from 2000 to 2050 impact the mercury concentration in the atmosphere. The GEOS-Chem model shows that the mercury concentrations for all tracers (1 to 3), elemental mercury $(\mathrm{Hg}(0))$, divalent mercury $(\mathrm{Hg}(\mathrm{II}))$ and primary particulate mercury $(\mathrm{Hg}(\mathrm{P}))$ have differences between 2000 and 2050 in most regions over the world.

\section{GEOS-CHEM/GCAP MODEL DESCRIPTION}

GEOS-Chem model is a global 3-D chemical transport model (CTM) for atmospheric composition driven by meteorological fields from the Goddard Earth Observing System (GEOS) of the NASA Global Modeling and Assimilation Office. It is used to simulate the emissions, transport, chemical evolution and deposition of a wide range of chemical species in the atmosphere. GEOS-Chem can resolve more than 80 chemical species and 300 reactions. The model is usually initialized with a "restart" file containing concentrations for each species in each grid box. To allow the model to reach chemical equilibrium, a "spin-up" period of typically 6 to 12 months is used for all model runs. The GEOS data are available as a continuous archive from 1979 to present. The operational GEOS-Forward Processing product (GEOS-FP) product has a horizontal resolution of $0.25^{\circ}$ latitude $\mathrm{x} 0.3125^{\circ}$ longitude, with 72 levels in the vertical. The consistent MERRA-2 reanalysis product for 1979-present has a horizontal resolution of $0.5^{\circ}$ latitude $\mathrm{x} 0.625^{\circ}$ longitude, again with 72 levels in the vertical. Both products are generated by the GEOS-5 Data Assimilation System (DAS) from a cubed-sphere simulation with the GEOS-5 general circulation model (GCM). The high-performance GEOS-Chem (GCHP) can use the cubedsphere output. GEOS-Chem simulations can be conducted at the native resolution, at lower resolution, or in a nested mode with native resolution over selected regions. GEOS-Chem is gridindependent and compatible with the Earth Science Modeling Framework (ESMF), so that it can be used as a stand-alone chemical module in Earth System Models (ESMs). The ESMF framework also enables GEOS-Chem simulations to be conducted using GCHP on massively parallel computing architectures with Message Passing Interface (MPI) protocol (http://acmg.seas.harvard.edu/geos/).

\section{SIMULATION EXPERIMENTS BASED ON GEOS- CHEM/GCAP MODEL}

We simulated mercury (Hg) emissions, chemistry, and atmospheric deposition using the GEOS-Chem model, described in detail by (Selin et al. 2007, 2008), with updates described by the published paper (Selin and Jacob.2008). The GEOS-Chem simulation has been extensively evaluated against atmospheric concentration and deposition measurements and matches seasonal and spatial trends (Selin et al. 2007, 2008). For the simulations in this paper, the tracers we used are tracers 1-3 (three species of mercury in the atmosphere): elemental mercury $(\mathrm{Hg}(0))$, divalent mercury $(\mathrm{Hg}(\mathrm{II}))$, and primary particulate mercury $(\mathrm{Hg}(\mathrm{P}))$. For this study to predict atmospheric mercury concentrations, the model uses simulated meteorological fields 
from the NASA/GISS Model 3 data as input, including winds, mixed layer depths, temperature, precipitation, and convective mass fluxes. GCAP is a special version of GEOS-Chem model which stands for 'Global Change and Air Pollution'. It is used to simulate and detect the atmospheric chemicals concentrations in the future. For example, in this paper, we take advantage of GCAP to simulate the mercury concentration in 2049-2051 years so as to make the comparison of mercury concentration between 2000 and 2050 in the atmosphere. We compile the GCAP model by the GEOS-Chem model version 8-03-01. Our simulation is conducted for two 3-year periods (1999-2001 and 2049-2051) by GCAP, with the first 3 years (1999-2001) used to get the 3-year average values of $\mathrm{Hg}(0), \mathrm{Hg}(\mathrm{II})$ and $\mathrm{Hg}(\mathrm{P})$, respectively in the year 2000 and the last 3 years (2049-2051) used for getting the 3-year average value of $\mathrm{Hg}(0), \mathrm{Hg}(\mathrm{II})$ and $\mathrm{Hg}(\mathrm{P})$, respectively in the year 2050. It uses simulated meteorological fields from the NASA/GISS Model 3 data as input, including winds, mixed layer depths, temperature, precipitation, and convective mass fluxes. This GCAP meteorological field used by GEOS-Chem is containing A3 fields which are 3-hour time averages, centered on 01:30 04:30 07:30 ... 22:30 GMT, A6 fields which are 6-hour time averages, centered on 00:00 06:00 12:00 18:00 GMT, I6 fields which are 6-hour instantaneous fields, centered on 00:00 06:00 12:00 18:00 GMT and Constant fields which are time-invariant. We focus most of our analyses on the comparison between the mercury data for year 2000 and 2050. By the comparison, we try to get our conclusion about how the climate changes from 2000 to 2050 impact the mercury concentration in the atmosphere. The $\mathrm{Hg}(0)$ 's resident time is about one year due to its relatively slow oxidation to the mercuric state (divalent mercury). This time is sufficient for atmospheric mercury to be distributed over the entire planet before returning to the land, lakes, sea, and ice. And the troposphere provides effective global transport of $\mathrm{Hg}(0)$. The model does not include all oxidation and reduction pathways, instead, GEOS-Chem only includes the most major pathway for either oxidation or reduction. The model includes $\mathrm{Hg}(0)$ oxidation to $\mathrm{Hg}(\mathrm{II})$ by $\mathrm{OH}$ (Pal and Ariya, 2004a; Sommar et al., 2001) and ozone (Hall, 1995). Oxidation rates are calculated using archived monthly mean 3-D fields of $\mathrm{OH}$ and O3 concentrations from a detailed GEOS-Chem tropospheric chemistry simulation (Park et al., 2004). For reduction, the model includes the aqueous-phase photoreduction of $\mathrm{Hg}$ (II) as the only reduction pathway. In the model, this photoreduction pathway is based on estimate of rate constant and scaled to $\mathrm{OH}$ concentration. Reduction rates are also calculated using archived monthly mean 3-D fields of $\mathrm{OH}$ concentration from a detailed GEOS-Chem tropospheric chemistry simulation (Park et al., 2004). The model also includes the sum of oxidation of $\mathrm{Hg}(0)$ and reduction of $\mathrm{Hg}(\mathrm{II})$ which is production of $\mathrm{Hg}(\mathrm{II})$ from $\mathrm{Hg}(0)$. The model simulates both wet and dry deposition fluxes for divalent mercury $(\mathrm{Hg}(\mathrm{II}))$ and primary particulate mercury (Hg(P)) but only dry deposition flux for elemental mercury (Hg(0)) (Selin and Jacob 2008). For divalent mercury (Hg(II)), the total deposition amount is largest among the three tracers while the dry deposition dominates over the wet deposition (dry deposition:4700 Mg/year, wet deposition: $2100 \mathrm{Mg} /$ year) (Selin.2007). The dry deposition amount of primary particulate mercury $(\mathrm{Hg}(\mathrm{P}))$ is almost neglected since the wet deposition is $190 \mathrm{Mg} /$ year while the dry deposition is only $10 \mathrm{Mg} /$ year (Selin.2007). The most deposition of elemental mercury $(\mathrm{Hg}(0)$ ) happens after the oxidation of elemental mercury $(\operatorname{Hg}(0))$ to divalent mercury $(\mathrm{Hg}(\mathrm{II}))$. So, there is no specific deposition amount of elemental mercury $(\mathrm{Hg}(0))$ included in GEOS-Chem model (Selin.2007).

\section{RESUlTS DisCUSSION}

The Figure. 1 shows the simulated result by GCAP for 3-year average $\operatorname{Hg}(0)$ concentration for year 2000 and year 2050, respectively in the top panel and the $\mathrm{Hg}(0)$ concentration difference by (2050-2000) and (2050-2000)/2000 percentage in the bottom panel. This Figure examines more specifically the change in the global distribution of $\mathrm{Hg}(0)$ (3-year mean concentrations). Since we use the Global Emission Inventory Activity (GEIA) global inventory of anthropogenic emissions for the year 2000 for Present-day (2000) and the future (2050), the change in the global distribution of $\mathrm{Hg}(0)$ surface concentration from 2000 to 2050 is due to the climate change. From the (2050-2000) concentration difference plot in the bottom panel, we can see that change in climate decrease $\mathrm{Hg}(0)$ surface concentration in most of the world. Either decreasing reduction from divalent mercury $(\mathrm{Hg}(\mathrm{II}))$ or increasing oxidation to divalent mercury ( $\mathrm{Hg}(\mathrm{II})$ ) could be the important factor for the surface concentration of elemental mercury $(\mathrm{Hg}(0))$ decline.
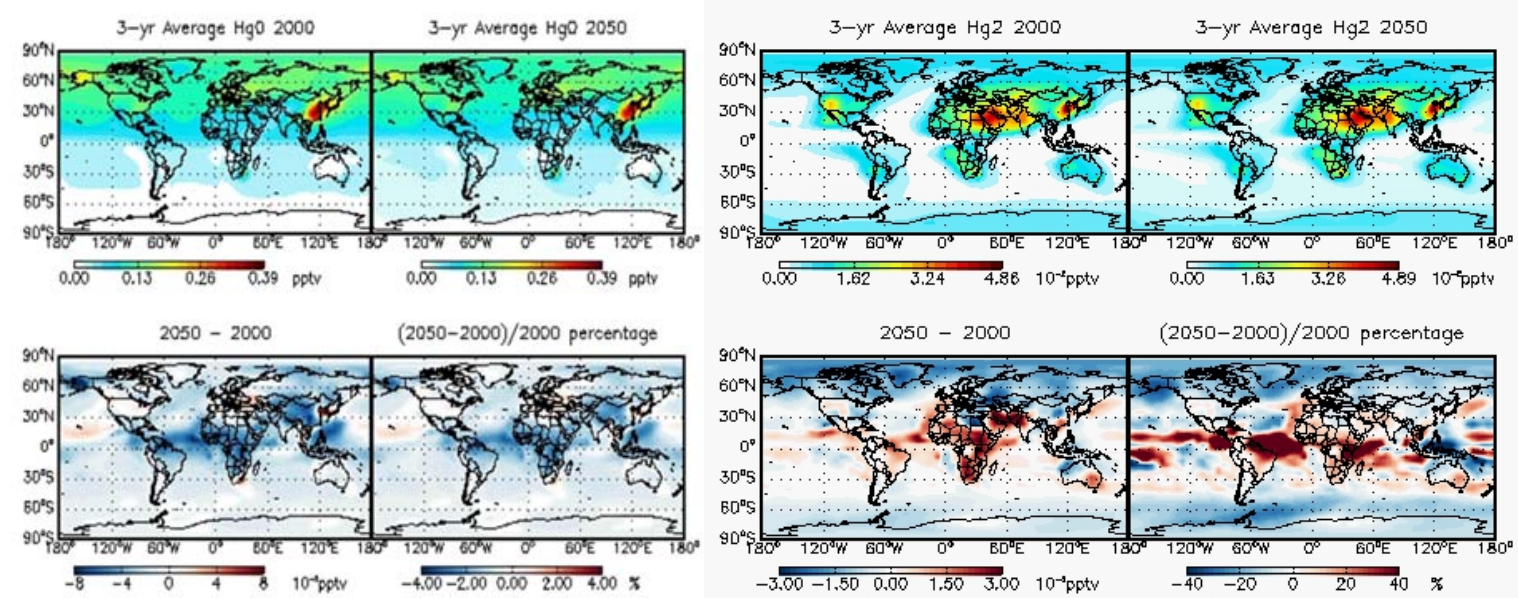

FIGURE I. SIMULATED RESULT BY GCAP 
The Figure. 2 shows the simulated result by GCAP for 3-year average divalent mercury $(\mathrm{Hg}(\mathrm{II})$ ) surface concentration for 2000 and 2050, respectively in the top panel and the $\mathrm{Hg}$ (II) concentration difference by (2050-2000) and (2050-2000)/2000 percentage in the bottom panel. This figure examines more specifically the change in the global distribution of divalent mercury (Hg(II)) (3-year a global inventory of anthropogenic emissions for the year 2000 for Present-day (2000) and the future (2050), the change in the global distribution of divalent mercury (Hg(II)) surface concentration from 2000 to 2050 is due to the climate change. From the (2050-2000) concentration difference plot in the bottom panel, we can see that climate change affect the divalent mercury $(\mathrm{Hg}(\mathrm{II}))$ surface concentration in a much more complicated way than affect the elemental mercury $(\mathrm{Hg}(0))$ surface concentration. Climate change increase the divalent mercury (Hg(II)) surface concentration in most of mid-latitude continental parts of the world, such as the whole Africa continent and the major part of south Asia. At the same time, Climate change decrease the divalent mercury (Hg(II)) surface concentration in most of high-latitude part of the world. We can also see this point more clearly by using the (2050-2000)/2000 percentage plot in lower panel of Figure.2. Since the factor of
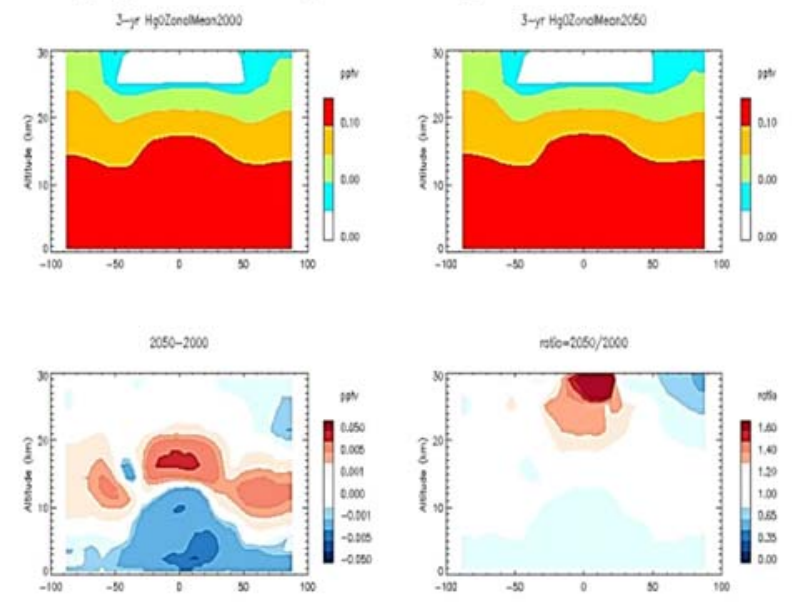

transformation between elemental mercury $(\mathrm{Hg}(0))$ and divalent mercury (Hg(II)) plays an important role on surface concentration differences between 2000 and 2050 for both elemental mercury $(\mathrm{Hg}(0))$ and divalent mercury $(\mathrm{Hg}(\mathrm{II}))$. We do the zonal mean difference plots for 3-year average elemental mercury $(\mathrm{Hg}(0))$ and divalent mercury (Hg(II)) between 2000 and 2050 other than the surface layer plots of the 3-year average elemental mercury $(\mathrm{Hg}(0))$ and divalent mercury $(\mathrm{Hg}(\mathrm{II})$ ) concentration comparison between 2000 and 2050 as Figure.1 and 2 showing. From Figure. 3 and 4, we can get the elemental mercury $(\mathrm{Hg}(0))$ and divalent mercury (Hg(II)) concentration changes for altitude from surface up to 30 kilometers. The major conclusion we obtain from the difference plots in Figure. 3 and 4 is that there must be some transformations between elemental mercury $(\mathrm{Hg}(0))$ and divalent mercury (Hg(II)) during 2000 to 2050. The major increasing part for elemental mercury $(\mathrm{Hg}(0))$ in Figure. 3 is closely matching the major decreasing part for divalent mercury $(\mathrm{Hg}(\mathrm{II}))$ in Figure.4. In the same way, the major decreasing part for elemental mercury $(\mathrm{Hg}(0))$ in Figure.3 is closely matching the major increasing part for divalent mercury (Hg(II)) in Figure.4.
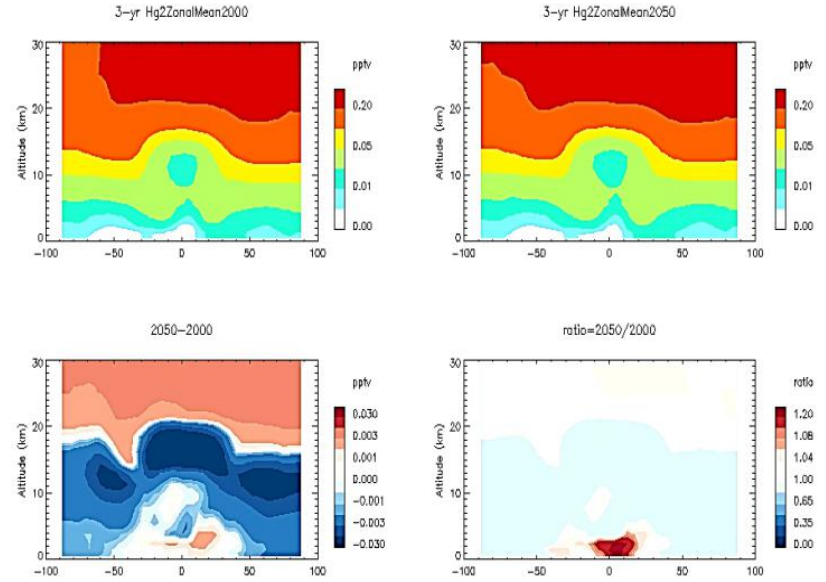

FIGURE II. THE ELEMENTAL MERCURY (HG(0)) AND DIVALENT MERCURY (HG(II)) CONCENTRATION CHANGES FOR ALTITUD

We have used a global 3-D atmospheric model (GEOSChem) to simulate mercury in the atmosphere for two 3-year periods (1999-2001 and 2049-2051), with the first 3 years (19992001) used for getting the 3 -year average value of $\mathrm{Hg}(0), \mathrm{Hg}(\mathrm{II})$ and $\mathrm{Hg}(\mathrm{P})$, respectively in 2000 and the last 3 years (2049-2051) used for getting the 3-year average value of $\mathrm{Hg}(0), \mathrm{Hg}(\mathrm{II})$ and $\mathrm{Hg}(\mathrm{P})$, respectively in 2050. The model version used in this research is "GCAP". From the model results, we can see that the climate change from 2000 to 2050 would decrease $\mathrm{Hg}(0)$ surface concentration in most of the world, only except in couple very small parts, for example north-eastern of China, south-eastern of South Africa and central part of Europe. The climate change from 2000 to 2050 would increase Hg(II) surface concentration in most of mid-latitude continental parts of the world, such as the whole Africa continent and the major part of south Asia. At the same time, decrease $\mathrm{Hg}$ (II) surface concentration in most of high-latitude part of the world.

\section{REFERENCES}

[1] Holmes, C.D., D.J. Jacob, E.S. Corbitt, J. Mao, X. Yang, R. Talbot, and F. Slemr, Global atmospheric model for mercury including oxidation by bromine atoms, Atmospheric Chemistry and Physics, 10, 12,037-12,057, 2010

[2] Allison, J. D., and T. L. Allison (2005), Partition coefficients for metals in surface water, soil and waste, Rep. EPA/600/R-05/074, U.S. Environ. Prot. Agency, Off. of Res. and Dev., Washington, D.C.

[3] Martinez-Cortizas, A., Pontevedra-Pombal, X., Garcia-Rodeja, E., Novoa-Munoz, J.C. and Shotyk, W., Mercury in a Spanish Peat Bog: Archive of Climate Change and Atmospheric Metal Deposition, Science, May 7, 1999.

[4] Jozef M.Pacyna, Elisabeth G. Pacyna, Frits Steenhuisen and Simon Wilson, Global Anthropogenic emissions of mercury to the atmosphere, The Encyclopedia Of Earth, August 29, 2008

[5] Selin, N.E. and D.J. Jacob. Seasonal and spatial patterns of mercury wet deposition in the United States: North American vs. intercontinental sources, Atmospheric Environment, 42, 5193-5204, 2008.

[6] Selin, N.E., D.J. Jacob, R.M. Yantosca, S. Strode, L. Jaegle, and E.M. Sunderland, "Global 3-D land-ocean-atmosphere model for mercury: 
present-day vs. pre-industrial cycles and anthropogenic enrichment factors for deposition", Global Biogeochemical Cycles , 22, GB2011.

[7] Selin, N.E., D.J. Jacob, R.J. Park, R.M. Yantosca, S. Strode, L. Jaegle, and D. Jaffe, Chemical cycling and deposition of atmospheric mercury: Global constraints from observations, J. Geophys. Res, 112, DO2308, doi:10.1029/2006JD007450, 2007

[8] GEOS-Chem model details introduction in Harvard University website: (http://acmg.seas.harvard.edu/geos/)

[9] The fish consumption advisories for USA in EPA website: (http://www.usgs.gov/themes/factsheet/146-00/fig4b.gif)

[10] Schroeder, W. H., and J. Munthe (1998), Atmospheric mercury-An overview, Atmos. Environ., 32, 809-822.

[11] Xiaohong Xu, Xiusheng Yang, David R. Miller, Joseph J. Helble, Robert J. Carley, Formulation of bi-directional atmosphere-surface exchanges of elemental mercury, Atmospheric Environment, 33(1999) 4345-4355, 1998

[12] Philip D. Nightingale, Gill Malin, Cliff S. Law, Andrew J. Watson, Peter S. Liss, Malcolm I. Liddicoat, Jacqueline Boutin, Robert C. UpstillGoddard, In situ evaluation of air-sea gas exchange parameterizations using novel conservative and volatile tracers, GLOBAL BIOGEOCHEMICAL CYCLES, VOL. 14, NO. 1, PP. 373-387, 2000

[13] X. Lin and Y. Tao, A numerical modelling study on regional mercury budget for eastern North America, Atmos. Chem. Phys., 3, 535-548, 2003

[14] Lamborg, C. H., W. F. Fitzgerald, J. O’Donnell, and T. Torgersen (2002), A non-steady-state compartmental model of global-scale mercury biogeochemistry with interhemispheric gradients, Geochim. Cosmochim. Acta, 66, 1105-1118.

[15] Edgerton, E. S., and J. J. Jansen (2004), Elemental Hg measurements in Atlanta, GA, USA: Evidence for mobile sources? paper presented at 7th International Conference on Mercury as a Global Pollutant, RMZ-Mater. and Geoenviron., Ljubljana, Slovenia.

[16] Lindqvist, O. and Rodhe, H. (1985). Atmospheric mercury - a review. Tellus 37B, 134. Slemr, F., Schuster, G., and Seiler, W., Distribution, speciation, and budget of atmospheric mercury, J. Atmos. Chem., 3, 407434, 1985

[17] Fitzgerald, L., Johnston, R., Brignall, T. J., Silvestro, R. and Voss, C., 1991. Performance Measurement in Service Businesses, C.I.M.A.

[18] Lee, Y.-H., and A. Iverfeldt. 1991. Measurement of methylmercury and mercury in runoff, lake and rain waters. Water Air Soil Pollut. 56:309321. Lamborg, C.H., Fitzgerald, W.F., Vandal, G.M., Rolfhus, K.R., 1995.

[19] Atmospheric mercury in northern Wisconsin: sources and species. Water, Air, and Soil Pollution 80, 189-198. Nicole St-Louis, M.J.Dalton, S.V.Marchenko, A.F.J.Moffat and A.J.Willis, The IUE Mega Campaign: Wind Structure and Variability of HD 50896 (WN5). THE ASTROPHYSICAL JOURNAL, 452:L57-L60, 1995 October 10

[20] Pal, B., and P. A. Ariya (2004a), Gas-phase HO-initiated reactions of elemental mercury: Kinetics and product studies, and atmospheric implications, Environ. Sci. Technol., 38, 5555- 5566.

[21] Sommar, J., K. Gardfeldt, D. Stromberg, and X. Feng (2001), A kinetic study of the gas-phase reaction between the hydroxyl radical and atomic mercury, Atmos. Environ., 35, 3049- 3054. Hall, B. (1995), The gas phase oxidation of elemental mercury by ozone, Water Air Soil Pollut., 80, 301315.

[22] Park, R. J., D. J. Jacob, B. D. Field, R. M. Yantosca, and M. Chin (2004), Natural and transboundary pollution influences on sulfate-nitrateammonium aerosols in the United States: Implications for policy, J. Geophys. Res., 109, D15204, doi:10.1029/2003JD004473.

[23] Mason, R. P., and G.-R. Sheu (2002), Role of the ocean in the global mercury cycle, Global Biogeochem. Cycles, 16(4), 1093, doi:10.1029/2001GB001440.

[24] Pleijel, K., and J. Munthe (1995), Modeling the atmospheric mercury cycle-Chemistry in fog droplets, Atmos. Environ., 29, 1441-1457.

[25] Lin, C.-J., and S. O. Pehkonen (1998), Two-phase model of mercury chemistry in the atmosphere, Atmos. Environ., 32, 2543-2558.

[26] Lin, C.-J., and S. O. Pehkonen (1999), The chemistry of atmospheric mercury: A review, Atmos. Environ., 33, 2067-2079.
[27] Liu, H., D. J. Jacob, I. Bey, and R. M. Yantosca (2001), Constraints from $210 \mathrm{~Pb}$ and $7 \mathrm{Be}$ on wet deposition and transport in a global threedimensional chemical tracer model driven by assimilated meteorological fields, J. Geophys. Res., 106, 12,109-12,128.

[28] Poissant, L., A. Amyot, M. Pilote, and D. R. S. Lean (2000), Mercury water-air exchange over the Upper St. Lawrence River and Lake Ontario, Environ. Sci. Technol., 34, 3069-3078.

[29] Clever, H. L., S. A. Johnson, and M. E. Derrick, The solubility of mercury and some sparingly soluble mercury salts in water and aqueous electrolyte solution, d. Phys. Chem. Ref Data, 14, 631-680, 1985

[30] Xu, X., Yang, X., Miller, D. R., Helble, J. J. and Carley, R. J., 1999: Formulation of bi-directional atmosphere surface exchanges of elemental mercury. Atmos. Environ., 33, 4345-4355.

[31] Poissant, L. and Casimir, A. (1998) Water-air and soil-air exchange rate of total gaseous mercury measured at background sites. Atmospheric Environment 32, 883-893.

[32] Y Zhang, Y Tian, Y Knyazikhin, J Martonchik, D Diner, M Leroy and R.B Myneni, Prototyping of MODIS LAI and FPAR algorithm with POLDER data over Africa, IEEE Trans. Geosci. Remote Sens., 38 (2000), pp. 2402-2418

[33] M.M. Lynam, G.J. Keeler, Source-receptor relationships for mercury in Urban Detroit, Michigan Atmospheric Environment, 39 (2006), pp. 3144 3155

[34] Lyatt Jaegle, Atmospheric Long-Range Transport and Deposition of Mercury to Alaska-A report to the Alaska Department of Environmental Conservation, May 10, 2010

[35] M. Young, The Technical Writer's Handbook. Mill Valley, CA: University Science, 1989. 